\title{
Psychological impact due to genital herpes among Central STD Clinic attendees in Sri Lanka
}

\author{
Jayasuriya NDV1, Sivayogan $\mathrm{S}^{2}$, Buddhakorale $\mathrm{K}^{3}$
}

\begin{abstract}
Background:

Genital herpes is becoming the most prevalent STI throughout the world during the last four decades ${ }^{1}$. It cannot be cured completely. Studies have identified that, genital herpes patients are more susceptible to psychological distress, possibly due to its natural history of incurability, asymptomatic viral shedding, recurrences, painful ulcers and risk of transmission to the partner and to the baby. Though there were studies published overseas to assess the psychological impact among patients with genital herpes, no such studies have been reported in Sri Lanka.
\end{abstract}

\section{Methodology:}

Objective: To study the psycho-social impact of HSV on patients attending the Central STD Clinic Sri Lanka. Study Setting: Central STD Clinic, Colombo. Study design: Cross sectional comparative study using HSV infected and non-infected patients who attended the STD clinic. Study population: Patients who attended the clinic having genital herpes infection and a comparative group from the same setting who did not have a genital herpes infection but having another STI at presentation. Sample size: Interviewer administered questionnaire was used on 85 genital herpes patients and 85 non infected patients. Study instrument: The study instrument included General Health Questionnaire (GHQ 30), the Hospital Anxiety and Depression Questionnaire (HADQ) and the questionnaire related to sociodemographic variables.

\section{Results:}

Each group was composed of 52 men and 33 women. The demographic differences among two populations were not statistically significant. Some social factors were different among two populations. Social stigmatization and the fear of transmitting to their partners were high among herpes group .This difference is statistically significant at $\mathrm{p}<0.001$. The psychological distress among herpes group $66 \%$ $(\mathrm{n}=56)$ was significantly higher at $\mathrm{p}<0.001$ than the non herpes group $29 \%(n=25)$. The level of anxiety and depression among herpes group was $35 \%(\mathrm{n}=30)$ and $23.5 \%(\mathrm{n}=20)$ respectively. For non herpes patients $15 \%(\mathrm{n}=13)$ and $9 \%(\mathrm{n}=8)$. The difference in the level of anxiety and depression among two groups was statistically significant at $p$ $<0.05$.

\section{Conclusion:}

Patients with genital herpes had more psychological distress, anxiety and depression compared to non herpes patients.

\section{Key words:}

Genital herpes, Psychological impact, Sri Lanka

\section{Introduction}

Genital herpes is one of the most common sexually transmitted infections in the world. It may be caused by either herpes simplex virus type 1 (HSV-1) or type 2 (HSV-2) but, globally, the large majority of cases are caused by HSV-2. The estimated total number of people aged 15-49 years who were living

\footnotetext{
' Senior Registrar in Venereology ${ }^{2}$ Professor in Community Medicine ${ }^{3}$ Consultant in Venereology

Corresponding author: Jayasuriya NDV, Email: nimmidvj@yahoo.com
} 
with HSV-2 worldwide in 2003 is 536 million ${ }^{2}$. National STD/AIDS Control Programme (NSACP) in Sri Lanka showed that, there were 2728 cases of genital herpes patients reported during $2013^{3}$.

Genital herpes is usually identifiable by its characteristic lesion: A thin-walled blister on an inflamed base of skin. Virus culture is the method of confirm the diagnosis. Genital herpes infection has no permanent cure, but is not fatal. However it carries a certain level of morbidity leading to a high anxiety level. Due to the incurable nature of the disease and recurrences, patient's sexual and social life could get affected. Genital ulcer disease, including HSV-2, is a well-recognized risk factor for the transmission of human immunodeficiency virus (HIV) 4.

There are no reported studies done in Sri Lanka regarding the psycho-social impact among patients with genital herpes and few studies have been carried out elsewhere. In 1994, in a study conducted at Academic Department of Genitourinary Medicine, University College and Middlesex School of Medicine, London, Carney et al reported that diagnosis of a first episode of genital herpes has a profound emotional effect on patients ${ }^{5}$. The main objective of this study is to assess the level of psychological impact due to genital herpes when compared with a group who are not having herpes.

\section{Methodology}

The study was a cross sectional comparative study, among patients attending central STD Clinic Colombo which is the main STD clinic in Sri Lanka. The study population was patients with herpes ulcers in their first episode or recurrent episode. The comparison group was patients who had other STI without any genital signs and symptoms. The comparison clinic attendee was the person who attended next to the person with HSV with no genital signs and symptoms. Sex was matched. All eligible patients diagnosed within three months were recruited in their second, third or fourth clinic visit.

Asymptomatic patients and serology positive for HSV 1/ HSV2, patients with multiple sexually transmitted diseases including HIV, cognitively impaired patients , patients who could not understand and speak Sinhala or English and patients less than 18 years were excluded from the study. The estimated sample size of 85 individuals was based on the study carried out in London ${ }^{5}$. The study instruments used for this study were General Health Questionnaire (GHQ 30), Hospital Anxiety Depression Scale (HAD scale), and the questionnaire on socio-demographic variables . Data collection was carried out by trained senior medical officers who work in the Central STD Clinic and supervised by the principal investigator. All questions were manually checked and data cleaning and coding was done by principal investigator. Data analysis was done by using SPSS-15 package. Ethical approval was obtained from the Sri Lanka Medical Association.

\section{Results}

\section{Socio-demographic characteristics (Table 1)}

There were 85 participants in each group, of which $61 \%$ were males: The mean age of the herpes population was $34(\mathrm{SD}=10.4)$. Range was $18-67$ years. Mean of the non herpes group was 36 $(\mathrm{SD}=16.8)$. Highest age was 62 where as lowest was 18. The mean age difference of two samples was not statistically significant at $p<0.05$. The study sample comprised Sinhalese 95\%, Tamil $3 \%$ and Muslims $2 \%$. More than half of patients were educated up to grade 11 or above, $57 \%$ among HSV group and $51 \%$ non herpes. $62 \%$ of herpes population was married or living together, where as non herpes group $47 \%$.

Occupation wise two populations were not similar. $28 \%$ of the herpes patients were unemployed, an opposed to, only one among non herpes group. 39\% were laborers, $26 \%$ army personnel or police and $16 \%$ drivers. $15 \%$ was retired and $13 \%$ laborers among non herpes patients. Although patients were reported from 16 districts, half were from Colombo followed by $14 \%$ from Gampaha District. Alcohol consumption was very low among the sample. $70 \%$ of the sample have never or used alcohol occasionally. 
Table 1: Comparison of socio-demographic characteristics of genital herpes group with non herpes group

\begin{tabular}{|c|c|c|}
\hline & $\begin{array}{l}\text { Genital herpes group }(\mathrm{n}=85) \\
\text { Number }(\%)\end{array}$ & $\begin{array}{l}\text { Non herpes group } \\
(\mathrm{n}=85) \\
\text { Number }(\%)\end{array}$ \\
\hline \multicolumn{3}{|l|}{ Sex: } \\
\hline Male & $52(61)$ & $52(61)$ \\
\hline Female & $33(39)$ & $33(39)$ \\
\hline $\begin{array}{l}\text { Age :Mean (s.d.) } \\
\text { (years) }\end{array}$ & $34(\mathrm{SD}=10.4)$ & $36(\mathrm{SD}=16.8)$ \\
\hline$<20$ & $1(1.2)$ & $6(7)$ \\
\hline $21-25$ & $19(22.3)$ & $13(15.3)$ \\
\hline $26-30$ & $21(24.7)$ & $13(15.3)$ \\
\hline $31-35$ & $21(24.7)$ & $8(9.4)$ \\
\hline $36-40$ & $8(9.4)$ & $13(15.3)$ \\
\hline$>40$ & $15(17.6)$ & $32(32.6)$ \\
\hline \multicolumn{3}{|l|}{ Race: } \\
\hline Sinhalese & $80(94.1)$ & $81(95.3)$ \\
\hline Tamil & $3(3.5)$ & $1(1.2)$ \\
\hline Muslim & $2(2.4)$ & $3(3.5)$ \\
\hline \multicolumn{3}{|l|}{ Level of education: } \\
\hline Less than grade 5 & $6(7.1)$ & $10(11.8)$ \\
\hline Grade 5-11 & $31(36.5)$ & $32(37.6)$ \\
\hline Above grade 11 & $48(56.4)$ & $43(50.6)$ \\
\hline \multicolumn{3}{|l|}{ Occupation } \\
\hline Unemployed & $24(28.2)$ & $1(1.2)$ \\
\hline Employed & $61(70.6)$ & $72(84.7)$ \\
\hline Retired & $1(1.2)$ & $12(14.1)$ \\
\hline \multicolumn{3}{|l|}{ Marital status: } \\
\hline Single & $5(17.6)$ & $29(34.1)$ \\
\hline Cohabiting/married & $62(72.9)$ & $47(55.3)$ \\
\hline Separated/divorced/widow & $8(9.5)$ & $9(10.6)$ \\
\hline \multicolumn{3}{|l|}{$\begin{array}{l}\text { Consumption of alcohol: } \\
\text { (males only) }\end{array}$} \\
\hline Never & $44(51.8)$ & $46(54.1)$ \\
\hline Daily & $3(3.5)$ & $2(2.4)$ \\
\hline Frequently & $2(2.4)$ & $5(5.9)$ \\
\hline Occasionally & $33(38.8)$ & $26(30.6)$ \\
\hline Others & $3(3.5)$ & $6(7.1)$ \\
\hline 50 & The Sri Lanka Journal of Vene & 1. 5, No. 1, Decembe \\
\hline
\end{tabular}




\section{Psycho social impact (Table 2)}

In addition to the health care workers, $58 \%$ of HSV patient's and $43 \%$ of non herpes patients' STI status was known by their marital or regular partner, friend or other family member. Out of them, $47 \%$ of herpes and $27 \%$ of non herpes group felt that they were stigmatized by the known people. This difference was statistically significant. (Chi.square 4.48, $\mathrm{df}=1$, $\mathrm{P}<0.03$ ). $23 \%$ of herpes group and $26 \%$ of non herpes patients had fear of being found out by other people. Fear of transmission to their partners was more among HSV patients $62 \%$ compared to $47 \%$ among non herpes group. This difference was statistically significant (Chi.square 15.06, $\mathrm{df}=1$, $\mathrm{P}<0.001$ )

Table 2: Comparison of psycho social impact of genital herpes group with non herpes group Genital herpes group Other STI group $(\mathrm{n}=85)$ $(\mathrm{n}=85)$ Statistical difference

Number $(\%)$ Number $(\%)$ Chisquare Pvalue

Awareness of their STI

status by others

Yes

$49(57.6)$

$43(57.6)$

0.85

0.386

No

(among known patients)

Yes

$23(47)$

$11(25.6)$

4.48

0.03

Significant at

No

25(51)

$32(74.4)$

$\mathrm{p}<0.05$

*Don't know

1(2)

0

Fear of being found out by others

(Among unknown patients)

Yes

$23(63.8)$

$28(66.7)$

0.06

0.8

No $13(36.2)$

Fear of transmitting

to the partner/s

Yes

$65(76.5))$

$40(47.1)$

15.06

$<0.001$

Significant at

No

$20(23.5)$
$45(52.9)$ 


\section{GHQ:}

Satisfactory

psychological status

$29(34.1)$

$60(70.6)$

22.66

$<0.00001$

Significant at

Psychological distress

$56(65.9)$

$25(29,4)$

$\mathrm{p}<0.001$

\begin{tabular}{|c|c|c|c|c|}
\hline \multicolumn{5}{|l|}{ Anxiety: } \\
\hline Not present & $33(38.8)$ & $51(60)$ & 8.996 & 0.0027 \\
\hline & & & & $\begin{array}{l}\text { Significant at } \\
\mathrm{p}<0.05\end{array}$ \\
\hline *Doubtful & $22(25.9)$ & $21(24.7)$ & & \\
\hline Definite & $30(35.3)$ & $13(15.3)$ & & \\
\hline \multicolumn{5}{|l|}{ Depression: } \\
\hline Not present & $47(55.3)$ & $63(74.1)$ & & \\
\hline *Doubtful & $18(21.2)$ & $14(16.5)$ & 6.15 & $\begin{array}{l}0.013 \\
\text { Significant at } \mathrm{p}\end{array}$ \\
\hline Definite & $20(23.5)$ & $8(9.4)$ & & $<0.05$ \\
\hline
\end{tabular}

*In calculation of the chi square don't know and doubtful was amalgamated with not present and no category.

\section{Discussion}

All health problems are likely to have a psychological impact on patients. However, with sexually transmitted infections (STI), the impact could be more as it is associated with societally and culturally unaccepted behaviours. People living with STIs are also frequently subjected to discrimination. Individuals who suffer from genital herpes are more susceptible to psychological distress compared to other STIs ${ }^{5}$. In this study, also a similar finding was observed.

The demographic differences in two samples were not significant. Level of education is an indirect measurement of the level of literacy. As many patients had studied up to grade 11 and above, they could be considered as a fairly educated. Certain occupations like military and police personnel, taxi drivers, factory workers and hotel workers are considered as more vulnerable to acquire STIs. Similar occupational groups were seen among the herpes group, but not among non herpes.
An online poll carried out among U.S. adults with genital herpes showed strong social stigma associated with genital herpes ${ }^{10}$. Similar finding was observed in this study, as majority of herpes patients, whose HSV status was known by their family members or friends, felt that they were stigmatized. Study carried out in US showed that $68 \%$ of herpes patients were concerned about transmitting to their partners ${ }^{6}$. Current study too showed, herpes group had significantly more fear of transmitting to their sexual partners than non herpes group. This study clearly proved that there was a statistically significant difference in psychological distress, anxiety and depression among herpes patients than non herpes patients. The study carried out in the Departments of Genitourinary Medicine (GUM), and Dermatology, Middlesex Hospital London ${ }^{5}$ also showed, significant difference in psychological distress, but not in anxiety and depression. The cultural differences among two countries would be a factor, which resulted this difference in anxiety and depression. 


\section{Conclusion:}

In this study, the demographic difference among herpes and non herpes group either having a STI or being asymptomatic were not significant. Psychosocial impact was more among genital herpes patients and large proportion of patients with genital herpes had psychological distress, anxiety and depression compared to non herpes patients.

\section{Recommendation:}

Genital herpes patients should be counseled as individuals or couples to reduce their emotional distress. Repeated counselling is recommended among patients with recurrent episodes. Symptomatic episodes should be treated with suppressive therapy to minimize the psychological impact related to signs and symptoms. Primary prevention also needs to be promoted among non infected people.

\section{Limitations}

This study was limited to the Central STD Clinic and this study cannot be generalized. Ideally patients could be selected randomly from peripheral STD clinics also. Recruiting an asymptomatic group of patients could be difficult.

\section{Conflict of interest}

Authors declare no conflict of interest

\section{Funding}

No funding

\section{References}

1. Holmes KK, PF Sparling eds . Sexually

Transmitted Diseases: $4^{\text {th }}$ edition .The McGrawHill Companies;2008. p 42.

2. Cowan FM, French RS, Mayaud P, Gopal R, Robinson NJ, Oliveira SA, et al.

Seroepidemiological study of herpes simplex virus types 1 and 2 in Brazil, Estonia, India, Morroco, and Sri Lanka. Sex Transm Infect. 2003, 79(4), 286-90.
3. Annual report: National STD/AIDS Control Programme: 2013. Annex 1: vi, xiv.

4. hivinsite.ucsf.edu/InSite?page $=\mathrm{kb}-05-03-02$

5. Carney O, Ross E, Bunker C, Ikkos G, Mindel A. A prospective study of the psychological impact on patients with a first episode of genital herpes: Genitourinary Medicine. 1994 February. 70(1).p40-45.

6. Genital herpes: stigma still strong -webmed 